\title{
A meta-study of the effect of thermodynamic parameters on the efficiency of geothermal power plants worldwide
}

\author{
Jessica MacKinnon', Tomas Nancarrow ${ }^{2}$ and Oscar Nieves ${ }^{3, *}$ \\ University of Technology Sydney, Faculty of Science, P.O. Box 123, NSW 2007, Australia \\ ${ }^{1}$ Email: Jessica.A.Mackinnon@student.uts.edu.au \\ ${ }^{2}$ Email: Tomas.A.Nancarrow@student.uts.edu.au \\ ${ }^{3}$ Email: Oscar.A.Nievesgonzalez@student.uts.edu.au
}

*Author to whom correspondence should be addressed; Oscar.A.Nievesgonzalez@student.uts.edu.au DOI: http://dx.doi.org/10.5130/pamr.v3i0.1420

\begin{abstract}
As global energy demand rises, the search for viable alternative fuel sources continues. The practicality of geothermal energy to meet this demand is highly dependent on optimizing thermal efficiency. While geothermal energy is currently used in places like Western Australia for direct-heat applications such as leisure centres, developing a geothermal power plant in such an area depends on predicting which thermodynamic parameters optimize thermal efficiency. This metastudy focuses on the effect of geothermal operation parameters such as inlet pressure, temperature, mass flow rate, well depth and number of production wells on the thermal efficiency of geothermal power plants. Drawing data from 61 geothermal power plants around the world ranging in design capacity (MWe) and size, a meta-study on the thermal efficiency of plants operating under different thermodynamic cycles, namely single-flash, double-flash, binary Organic Rankine Cycle (ORC) and Kalina, is offered. These various thermodynamic parameters are analysed to determine the presence of observable thermal efficiency patterns or trends that may lead to the optimization of operation parameters for new geothermal plants. Based on the available published data reviewed, there are few trends which indicate how geothermal operation parameters affect thermal efficiency. Well depth may be an indicator of efficiency for geothermal power plants using ORC and double-flash cycles, however further data is required to support this conclusion.
\end{abstract}

Keywords: geothermal power, Renewable energy Australia; Kalina cycle; double-flash cycle; organic Rankine cycle; Single-flash cycle; thermal efficiency; geothermal gradient; binary cycles; safety in geothermal plants; energy analysis. 


\section{Nomenclature}

\begin{tabular}{ll}
\hline$P$ & pressure $(\mathrm{MPa})$ \\
$V$ & volume $\left(\mathrm{m}^{3}\right)$ \\
$n$ & number of moles \\
$T$ & temperature $(\mathrm{K})$ \\
$\dot{m}$ & mass flow rate $(\mathrm{kg} / \mathrm{s})$, typically from reservoir \\
$Q$ & heat $(\mathrm{kJ})$ \\
$W$ & work $(\mathrm{kJ})$ \\
$\dot{W}$ & Net electric power output $(\mathrm{kWe})$ \\
$E$ & energy $(\mathrm{kJ})$ \\
$h$ & enthalpy $(\mathrm{kJ} / \mathrm{kg})$ \\
$\eta$ & efficiency, also referred to as cycle efficiency or thermal efficiency, refers mainly to $1^{\text {st }}$ law efficiencies in the cycles \\
\hline
\end{tabular}

\section{Introduction}

Amongst the many avenues for a suitable form of cleaner energy, the idea of using the earth's heat as a self-sustaining form of energy production that could be used on a commercial scale, this is now known as geothermal energy. While still greatly unused in Australia as a commercial source, geothermal energy is proving to be rather beneficial to other countries around the world. As Australia turns to alternative energy sources and away from traditional energy reserves of fossil fuels, geothermal energy could become a contender to fill that void.

\subsection{Thermodynamic principles behind $1^{\text {st }}$ and $2^{\text {nd }}$ laws, heat engines and efficiency}

The efficiency of any geothermal power plant depends on a number of different factors. These factors are often related to the $1^{\text {st }}$ and $2^{\text {nd }}$ law of thermodynamics. In the context of power generation, the $1^{\text {st }}$ law is described as follows: "The change in the internal energy of a system is equal to the change in heat and work done on or by the system". This means that for every component of the power plant, including heat pumps, exchangers, turbines, and more; there will be an associated change in the internal energy. In general, however, for a closed system: the total change in internal energy should be zero. Therefore any change addition or rejection of heat must equal the amount of work done on or by the system. This is under the assumption the energy losses in the system can be deemed negligible.

The $2^{\text {nd }}$ law in the context of power plants is defined as: "The total entropy change in a system is equal to the sum of the entropies of all its constituents and is always greater than zero" [1]. This means that entropy always increases. Entropy is a measure of the transfer of heat (energy) between a system and its surroundings at assumed to be around a common temperature. In regards to a real processes, entropy should increases with a change in time and this can be accounted for the irreversibility of this cycle. All real cycles are irreversible, and the double-flash, Kalina and ORC are no exceptions to this thermodynamic rule. Irreversibility also entails a loss in energy and thus efficiency will in a majority of cases be lower than $50 \%$ for most power generation systems. For a majority of geothermal plants, the efficiency of a system will be within the vicinity of $10 \%$, but given that the supply of heat from the 


\section{PAM Review 2016}

Earth is continuous; there are numerous advantages over other power generation systems such as solar and wind.

Apart from efficiency, exergy is something that is closely studied when analysing the performance of power plants. Exergy is defined as the amount of energy in a system that is available for doing work. Unlike energy, exergy can be destroyed, and is in fact destroyed every time there is a temperature change in a system. This is a direct consequence of entropy increase and irreversibility. The amount of exergy destroyed is often called anergy, and these two quantities can be used to describe how well a particular thermodynamic process or cycle utilises energy.

\subsection{Basic principles behind geothermal power generation}

Geothermal power plants operate under the same general principles, but their generator design determines their performance and viability of any geothermal plant rather than the location. The simplest type of geothermal plant is the dry-steam power plant, where steam from a hot underground water reservoir flows through a pipe directly into a turbine, which is in turn connected to a condenser where it is converted to water that serves as a coolant for some of the components of the plant. Depending on the design of the plant, many wells may need to be drilled to increase the mass flow rate of the geothermal fluid. Apart from this, injection wells must also be drilled in order to replenish the underground water reservoir with cold water. In this sense, the reservoir functions as a natural water heater. Rather than having use steam this being a limiting factor, modern designs seek to make the most of the heat carried by water into the plants obtaining as much energy as possible to run the power plants.

Well depth plays a major role in the energy output of various geothermal power plants. For instance, there is a considerable pressure drop between the wellhead (lowest point) and ground level, and since this pressure drop is inversely proportional to the diameter of the pipes used [2]; the deeper the well is, the larger the pipes that will be required to pump the geothermal fluid out. Shallower wells offer a significant advantage in this respect, but due to the lower temperatures of the water reservoirs, the geothermal fluid that can be extracted often comes as a mixture of two or more phases; which inhibits the use of dry-steam plant designs. Other factors that affect plant performance with respect to pipe diameter are reinjection rates, pipe friction and internal roughness, and absolute viscosity of the water.

Single-flash steam water plants in the other hand offer an alternative to regions limited to relatively shallow well depths, when the geothermal fluid is not pure steam but rather a mixture of steam and liquid water. They operate by separating these two phases using a cylindrical cyclonic pressure vessel oriented vertically with respect to the ground [2], allowing the two phases to be separated by gravity. The process whereby a pressurized liquid transitions to a mixture of water and vapour is called flashing, or partial evaporation. A single-flash system will only undergo one flashing process, whereas a double-flash system will undergo two. Depending on the conditions of the plant, the flashing may occur in different locations between the reservoir and the cyclonic vessel; but this information is often irrelevant in the thermodynamical workings of the system [2]. Pipe orientation also has an impact on the pressure-losses, as different types of flow can be encountered randomly during operation and are 
hard to predict analytically, and in most cases experimental trials must be conducted to make further predictions.

Geothermal power plants operate using one of two cycle categories: flash and binary. The main difference between the two is that in flash systems; the geothermal fluid comes directly into contact with the turbine (steam driven), whereas in binary systems the geothermal fluid transfers heat to a secondary fluid, referred to as a 'working fluid'; which then vaporises to drive the turbine [3].

In general, the type of thermodynamic cycle used in the design of the power plant can significantly alter the net power output as well as the overall cost of operation. This paper will focus on the four common cycles used in the design of geothermal power plants: single-flash, double-flash, Kalina and ORC (Organic Rankine Cycle), and thus analyse the optimum temperature operating range of each based on empirical data accumulated from various sources.

\subsection{Principles of operation for each thermodynamic cycle}

\subsubsection{Single-flash cycle}

The single-flash cycle consists of a few basic steps. First, geothermal fluid from the reservoir is pumped to the surfaces where it passes through a cyclone separator where the liquid-vapour mixture of steam is further separated into the two phases [2]. It then passes through a series of valves before it reaches the inlet of the turbine, where it is expanded to generate electric power. From the turbine, it passes back into a condenser and then into a cooling cycle (typically air cooling) where it is fed back into the system through injection wells (see figure 1 for a simplified diagram of the process). Singleflash power plants are the easiest to build and most cost-effective, but they have a serious disadvantage in that they require a geothermal fluid to be almost pure steam, and it must be $99.995 \%$ dry before it enters the turbine [2].

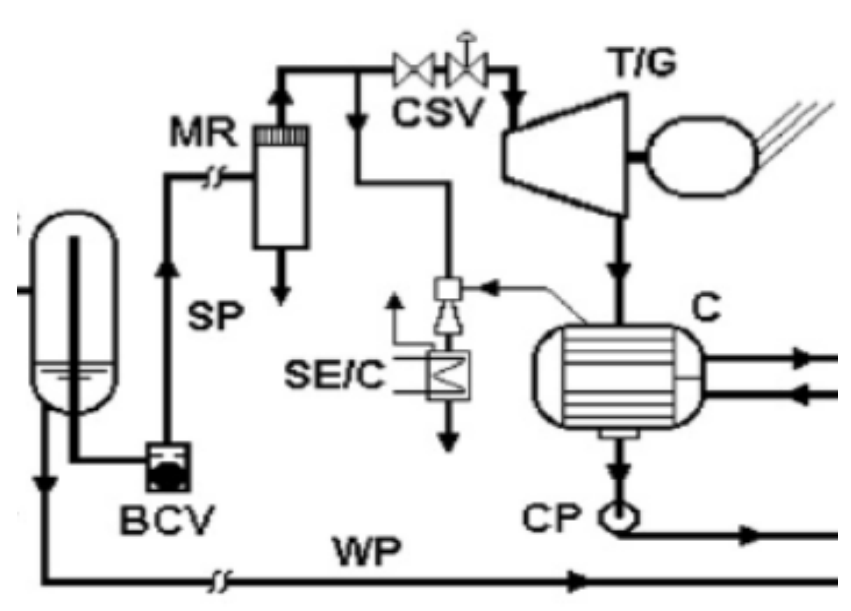

Figure 1. Schematic diagram of a single-flash geothermal plant with pipe leadings. [2]

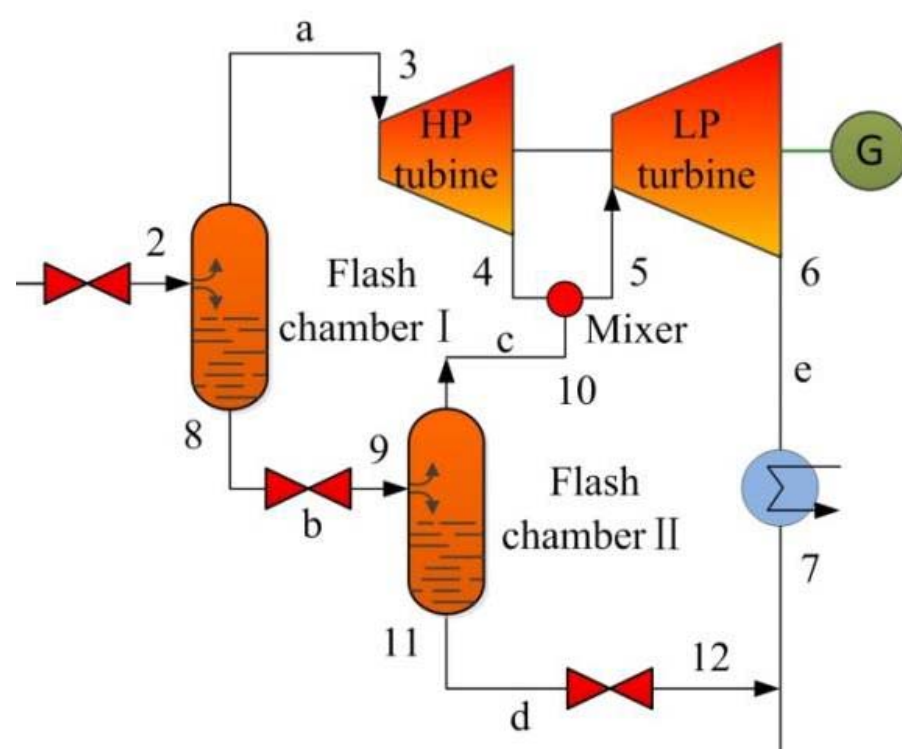

Figure 2. Schematic diagram of a double-flash cycle applied in geothermal power plant [3]

\subsubsection{Double-flash cycle}


Double-flash steam power plants can often produce on average anywhere between $15-25 \%$ more power output than single-flash plants within the same operating conditions [2]. The principle behind the double-flash cycle is in the use of two consecutive stages of flashing processes, as opposed to just one as in our previous example. A simplified diagram of the double-flash cycle is presented in figure 2. The cyclonic pressure vessel (labelled as "Flash chamber" in the diagram) separates the liquid-vapour mixture and the saturated water that is extracted, this is then fed into a second chamber where it undergoes the additional flashing process. The saturated steam from the second chamber is further mixed with the exhaust steam from the high pressure turbine to increase overall steam quality, which in turn improves the efficiency of the second cycle [3].

Figures 1 and 2 illustrate the main differences in plant designs employing single and double-flash cycles. Both cycles depend on cyclonic chambers to separate the liquid and vapour phases of the geothermal fluid. The double-flash cycle employs two cyclonic chambers in a sequence, such that the geothermal fluid undergoes two stages of flashing. This requires the addition of an extra turbine that functions as an intermediary in the process (at a high pressure), followed by a second turbine at a low pressure that powers the generator (shown in figure 2). The addition of a second flashing stage allows for the extraction of purer steam with less humidity than in single-flash systems, and as a result overall plant performance is enhanced [2]. One of the drawbacks of this, however, is that double-flash plants require more equipment and maintenance, hence increasing operation costs over single-flash power plants.

\subsubsection{Organic Rankine Cycle (ORC)}

The ORC operates with a binary fluid or working fluid, usually a hydrocarbon such as isopentane. The working fluid is chosen with the desired characteristic of having a lower boiling point and latent heat of vaporization than water, as a result the liquid-vapour transition occurs at a lower temperature than the geothermal fluid, allowing for heat recovery from low temperature sources typically below $200^{\circ} \mathrm{C}$ [4]. This cycle is comprised by four main stages [5] (see figure 3 for a simplified diagram):

1) Geothermal fluid extracted from the reservoir is injected into a vaporiser containing the working fluid, which turns into vapour after the heat is transferred to it.

2) The geothermal fluid then passes through a preheated where some of the residual energy is used to rise the temperature of the incoming working fluid which is injected into the vaporiser in step 1, and then reinjected into the reservoir underground.

3) The vaporised working fluid then powers the main turbine, and this is where the power generation occurs. As it passes through the turbine it is expanded, and in turn this causes a reduction in pressure in the fluid, as shown by the ideal gas equation $P V=\pi \cdot R T$. The low pressure fluid is fed into a recuperator to take advantage of any residual heat.

4) The working fluid is then passed through an air cooling system, after which it is transferred to the preheater for further use. 


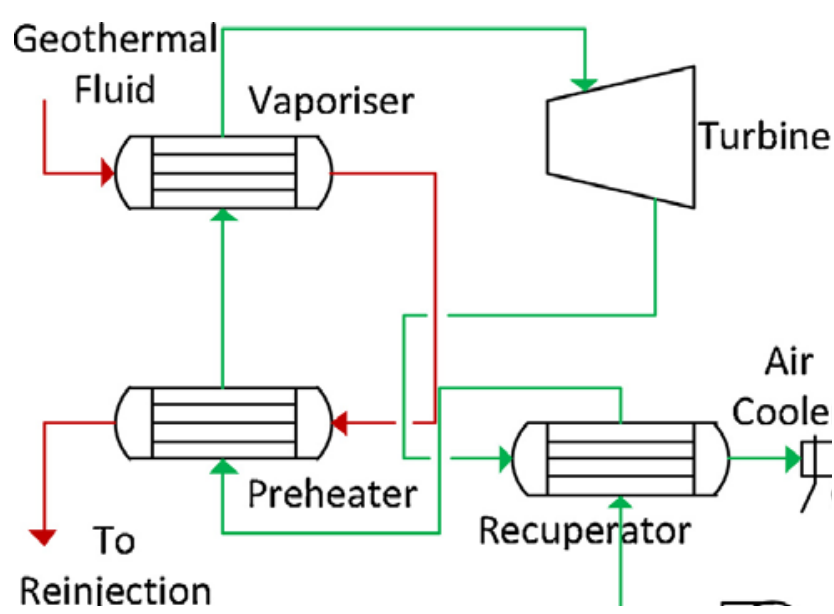

Figure 3. Simplified schematic of a geothermal ORC process [5].

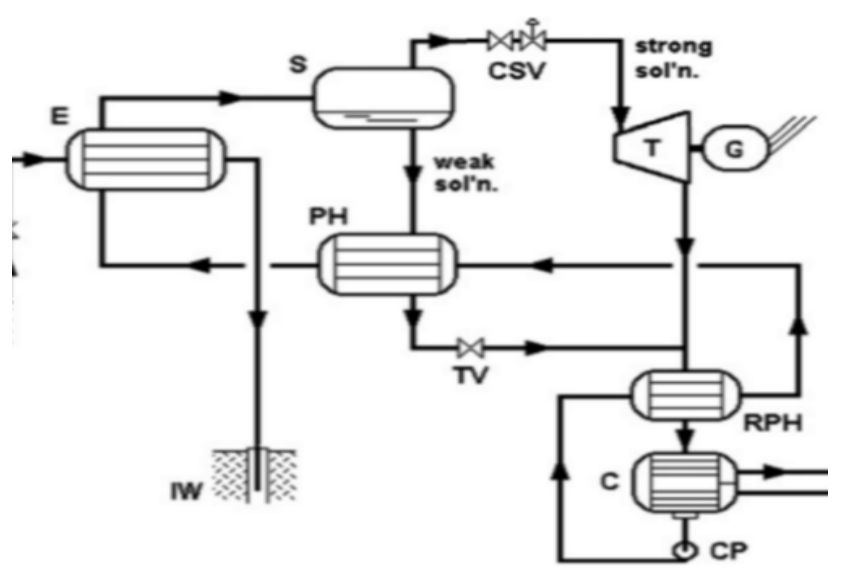

Figure 4. Simplified schematic of a geothermal Kalina cycle process [2]

An important point to take into account is that other cooling methods can also be used. In real applications however, many additional components may be required as different liquids will have different viscosities and affect various materials in any number of ways.

\subsubsection{Kalina cycle}

The Kalina cycle has long been the subject of study in geothermal energy and is now one of the most understood and efficient binary cycles to date [6]. "The Kalina cycle employs a multi-component zeotropic mixture of ammonia and water as its 'working' fluid. Although the cycle is based on an ideal Rankine vapour cycle, with additional absorption and distillation equipment required to reconstitute the mixture at the lower temperature end of the cycle". A summary of this cycle is presented as figure 4. "The separator, 'S', allows a saturated vapour that is rich in ammonia to flow through the turbine, thus permitting a smaller and less costly turbine than for a hydrocarbon working fluid. The weak solution, liquid rich in water, is used in a recuperative preheater RPH prior to being fully condensed" [2]. As stated from DiPippo 2012; "The working fluid is a binary mixture of $\mathrm{H} 2 \mathrm{O}$ and NH3; evaporation and condensation occur at variable temperature; the incorporation of heat recuperation from turbine exhaust; composition of the mixture may be varied during cycle in some versions" (DiPippo, 2012).

As it can be observed in figures 3 and 4, both ORC and Kalina cycles consist of the same setup and equipment, with the main difference being the type of working fluid. In most operating geothermal plants, ORC utilises pentane and isopentane, whereas Kalina uses an ammonia-water mixture with at least $70 \%$ ammonia for higher efficiency [2]. Another key difference between both binary cycles is shown in Fig.4. with the addition of a separator unit, similar to the cyclonic chambers used in flash cycles, and this allows for the separation of the two phases in the ammonia-water fluid.

\subsection{Operating conditions for possible Perth Basin (Western Australia) plants.}


One of the regions currently being considered for geothermal energy production is the Perth Basin in Western Australia. This basin extends approximately 1,000 km across south Western Australia [7]. The data gathered by Sheldon et al [7] suggests that the mean temperature gradient for the Yarragadee Formation is approximately $25.5 \pm 4.7^{\circ} \mathrm{C} / \mathrm{km}$, while in the northern regions the temperature gradients can be as high as $55{ }^{\circ} \mathrm{C} / \mathrm{km}$. This suggests that geothermal fluid temperatures of approximately $110{ }^{\circ} \mathrm{C}$ could be reached at just $2 \mathrm{~km}$ of well depth, and up to $165^{\circ} \mathrm{C}$ at $3 \mathrm{~km}$ depth; hence making this a suitable low-temperature geothermal source for domestic electricity production. The viability of this region has also been studied by Pujol et al [8], in which it is mentioned that shallower wells within a depth range of $750-1150 \mathrm{~m}$ at the Yarragadee Formation could also be used as direct-heating sources for other applications including leisure centres, outdoor pools and even house heating. However, the areas in the northern Perth Basin regions offer a better option for geothermal power generation due to its larger geothermal gradient, so this region will be the main focus of discussion in this paper to act as a situation into which of the plant designs would be the more effective and viable to use.

\section{Methods}

This meta-study was performed by accessing different open access databases such as Scopus and Google Scholar as a means of performing an unlimited search. The research conducted involved gathering actual power plant data from many different sources collected around the world. Much of this data came from countries with a high usage of geothermal resources such as New Zealand, Mexico, Iceland, Japan, USA, Turkey, Indonesia and the Philippines. From all the data and information gathered our group had looked into the best means of presenting the data in both a tabulated form (Appendix A) and a series of graph presented in our results section. Not all the data points required could be found for all the sources found, so this had to be taken into account in the analysis section. One possible reason for this, as identified by our research efforts, was that most power plants do not openly publish their performance parameters other than average yearly power production (often quoted in MWe), so most of the information that was found came from third party research articles and/or conference papers.

The analysis consisted of graphing thermal efficiency against different performance variables such as pressure, temperature, flow rate any form of data thermodynamically related. In order to look for any correlation between the data points our group had constructed a series of graphs. Points on the plots were categorized according to the type of thermodynamic cycle used by the respective geothermal plant, so as to allow for a comparison of the different cycles with respect to each variable. Only power plants for which thermal efficiency was found were taken into account, each dot point can simple be cross referenced with its data located in Appendix A.

Where plant efficiency data was not available but reservoir enthalpy $(\mathrm{kJ} / \mathrm{kg})$ was, the efficiency was estimated as the thermal efficiency (or $1^{\text {st }}$ law efficiency) using the following equation:

$$
\eta_{t h}=\frac{W}{\phi}=\frac{W}{m h}
$$


In a similar manner, where exergy efficiency was absent, the exergy efficiency was calculated as second law efficiency by dividing the thermal efficiency by the ideal Carnot efficiency:

$$
\eta_{e x}=\frac{\eta_{L_{C}}}{\eta_{C}}=\frac{T_{H}}{T_{E}-T_{C}} \eta_{t h}
$$

Where $T_{E}$ and $T_{C}$ are the temperatures of the hot and cold reservoirs (in Kelvin), respectively. In the context of this study, $T_{H}$ was taken as the maximum reservoir temperature for the geothermal power plant, and $T_{C}$ was kept constant at room temperature $300 \mathrm{~K}$ (which is the temperature expected in the last stage of the power station, where power is transmitted from the turbine into the electric generator).

Where net electric power output $\dot{W}$ was not provided, it was taken as $50 \%$ of the maximum plant capacity for majority of cases. The reason for this choice is that throughout an annual period, geothermal power plants usually operate well below maximum capacity. These actual values fluctuate significantly with time, which explains the absence of this information in most performance reports and conference papers. The assumption of a 50\% operating capacity accounts for worst-case scenario conditions that may hinder the performance of the geothermal power plant, and also takes into account the fact that theoretical efficiencies are usually overestimated with respect to real efficiencies.

\section{Results and Discussion}

The variables we decided to investigate were chosen according to how often they were quoted with respect to thermal efficiency in the literature, and included: reservoir temperature, maximum well depth, reservoir enthalpy, number of production wells (used for geothermal fluid extraction), turbine inlet pressure, and mass flow rate of the steam or working fluid. These parameters were compiled into various graphs, and from these we attempted to find any trends in the data that may suggest a correlation between these parameters and plant efficiency. This analysis included 61 plants from all over the world as a means to compare which plant design and thermodynamic cycle would be the most suitable to implement in the Perth Basin. Figures 5-10 illustrate how thermal efficiency varies with these parameters, whereas figures 11-15 show the relation between exergy efficiency and these variables. In total, 61 geothermal plants were included in the analysis. Note that not all the data compiled in this meta-study is portrayed in each graph, as some of the information was not available. 


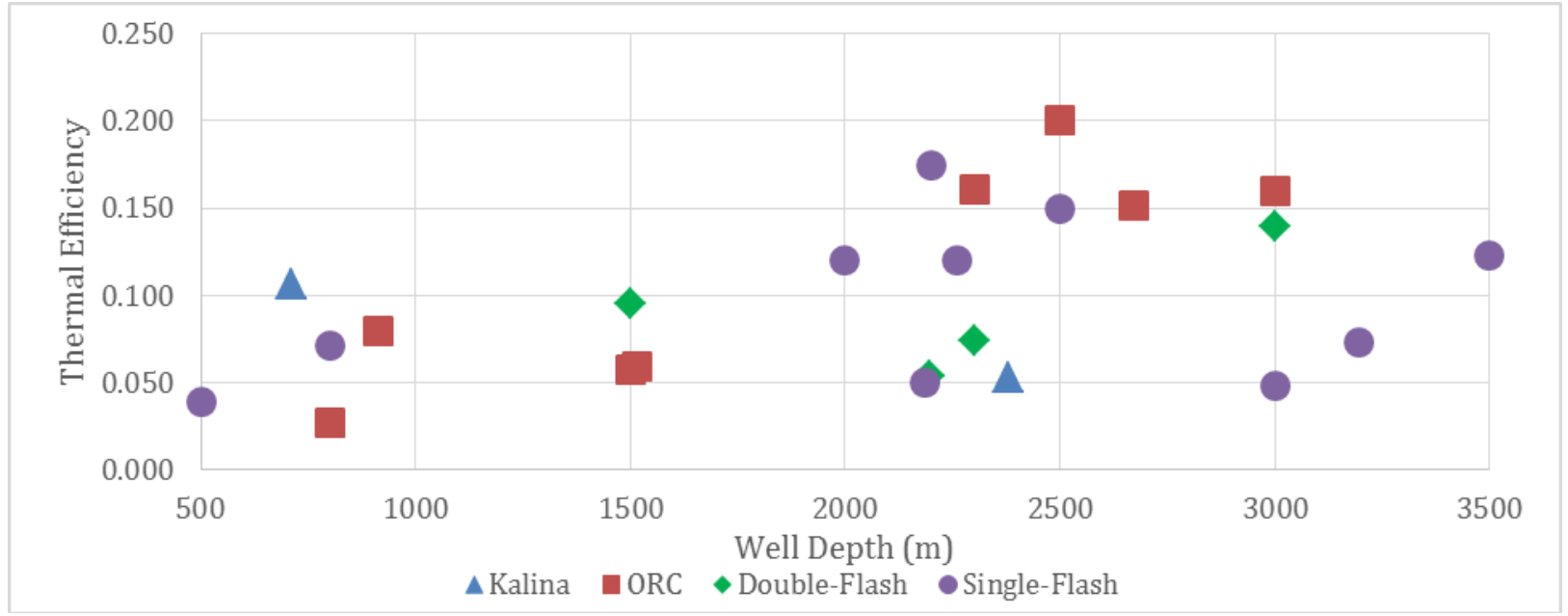

Figure 5. Thermal efficiency variation with maximum well depth.

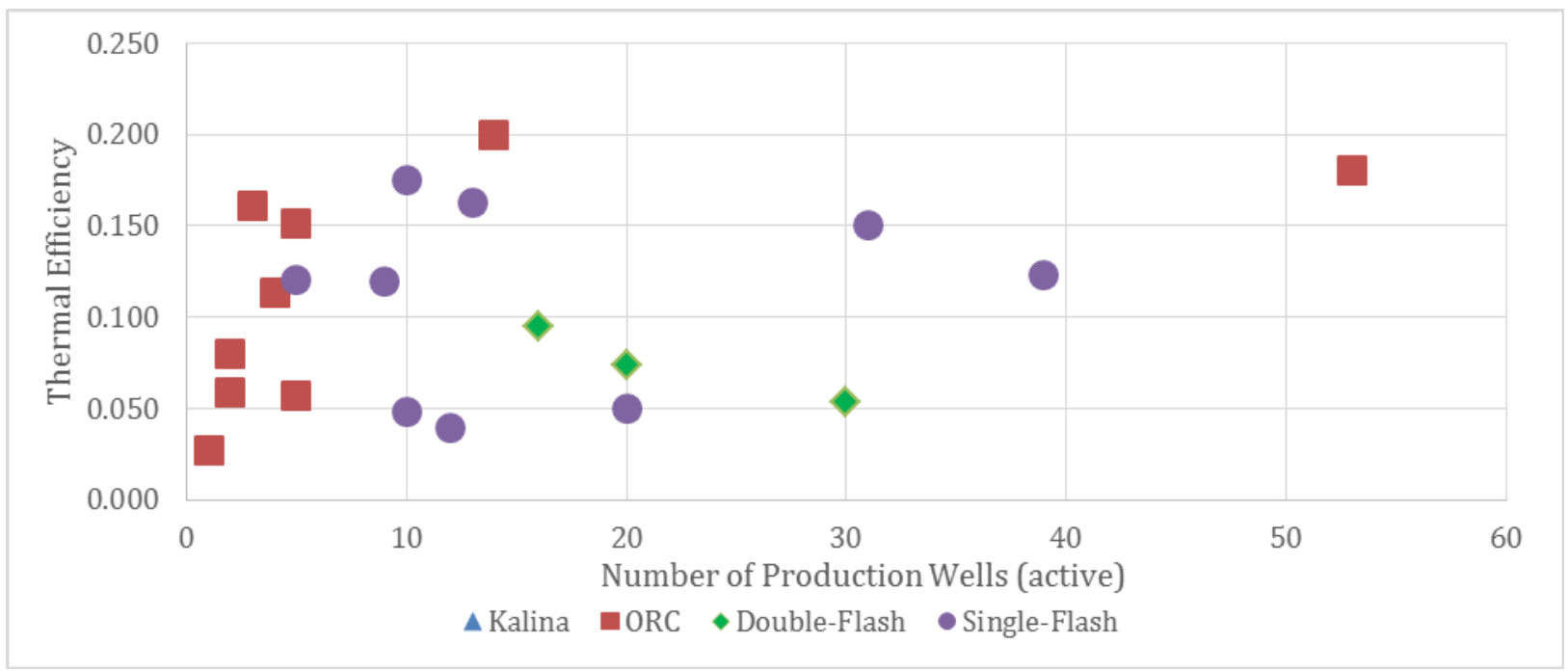

Figure 6. Thermal efficiency variation with number of active production wells.

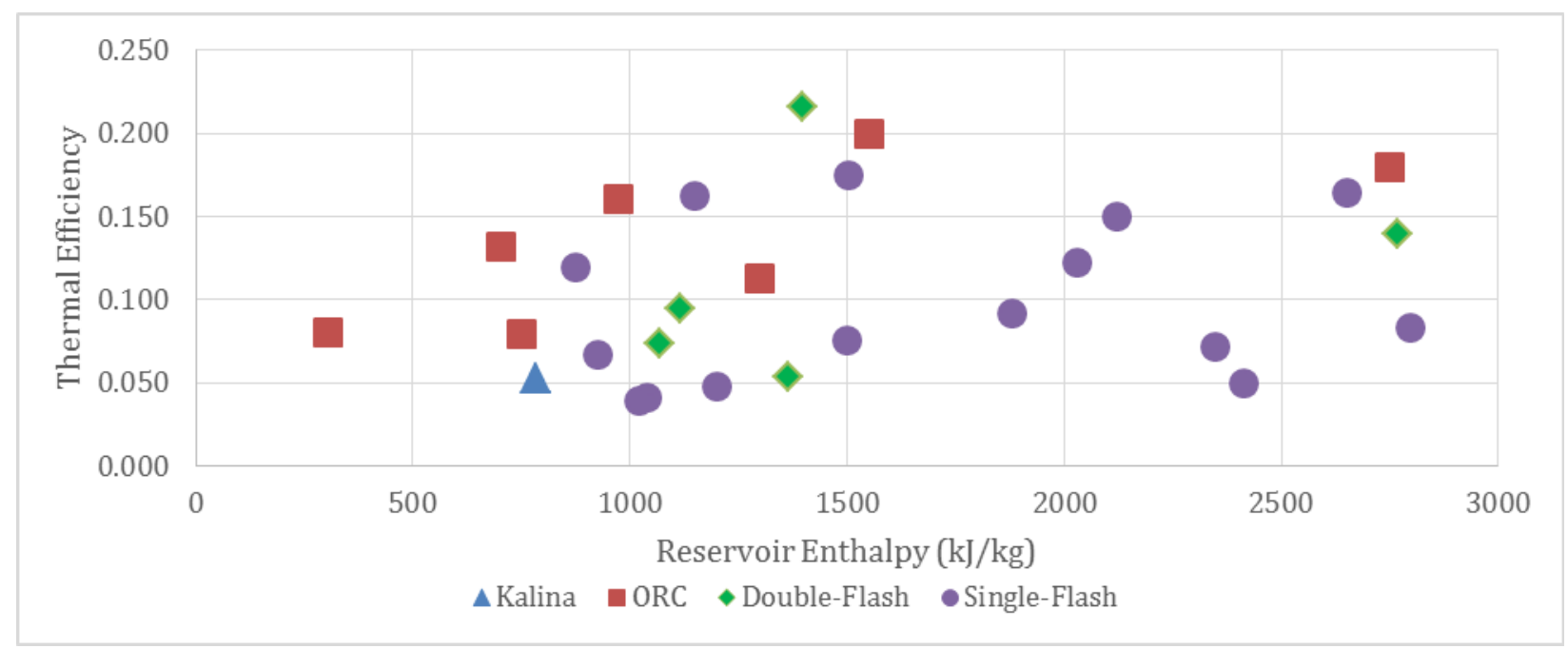

Figure 7. Thermal efficiency variation with reservoir enthalpy. 


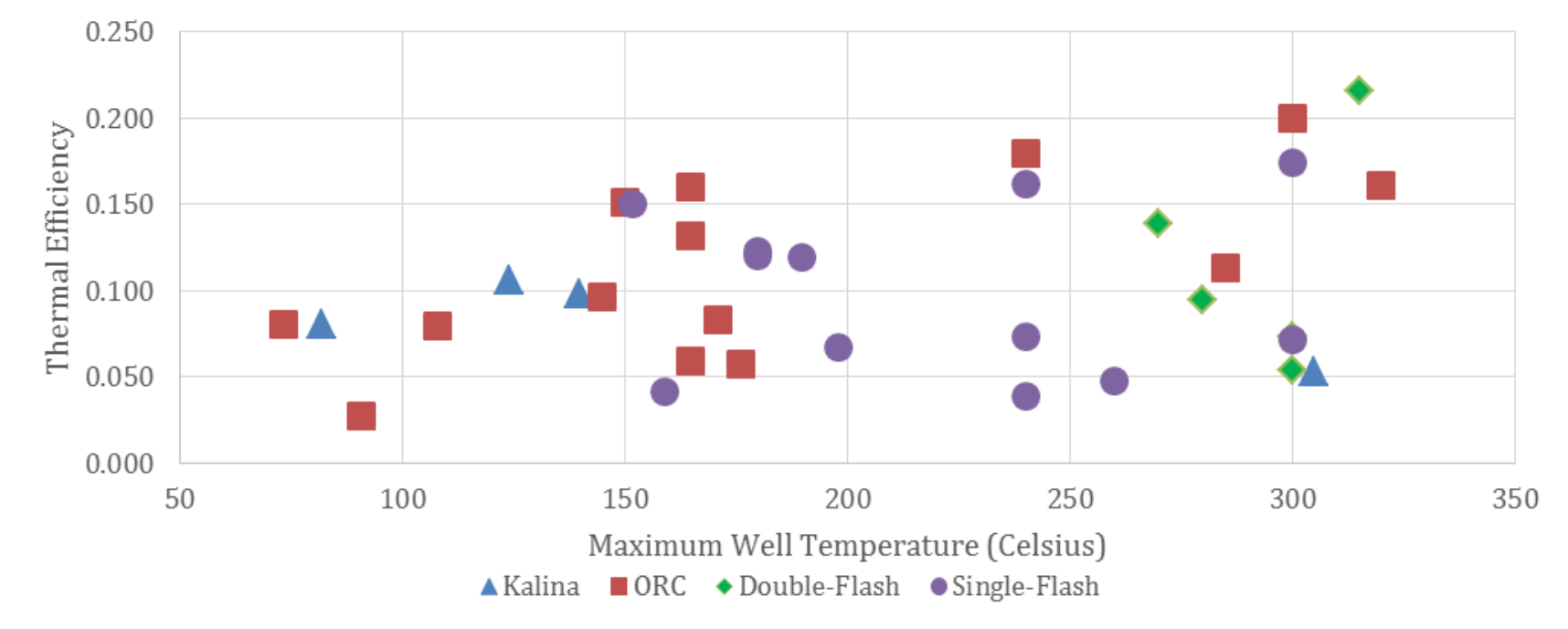

Figure 8. Thermal efficiency variation with maximum well temperature.

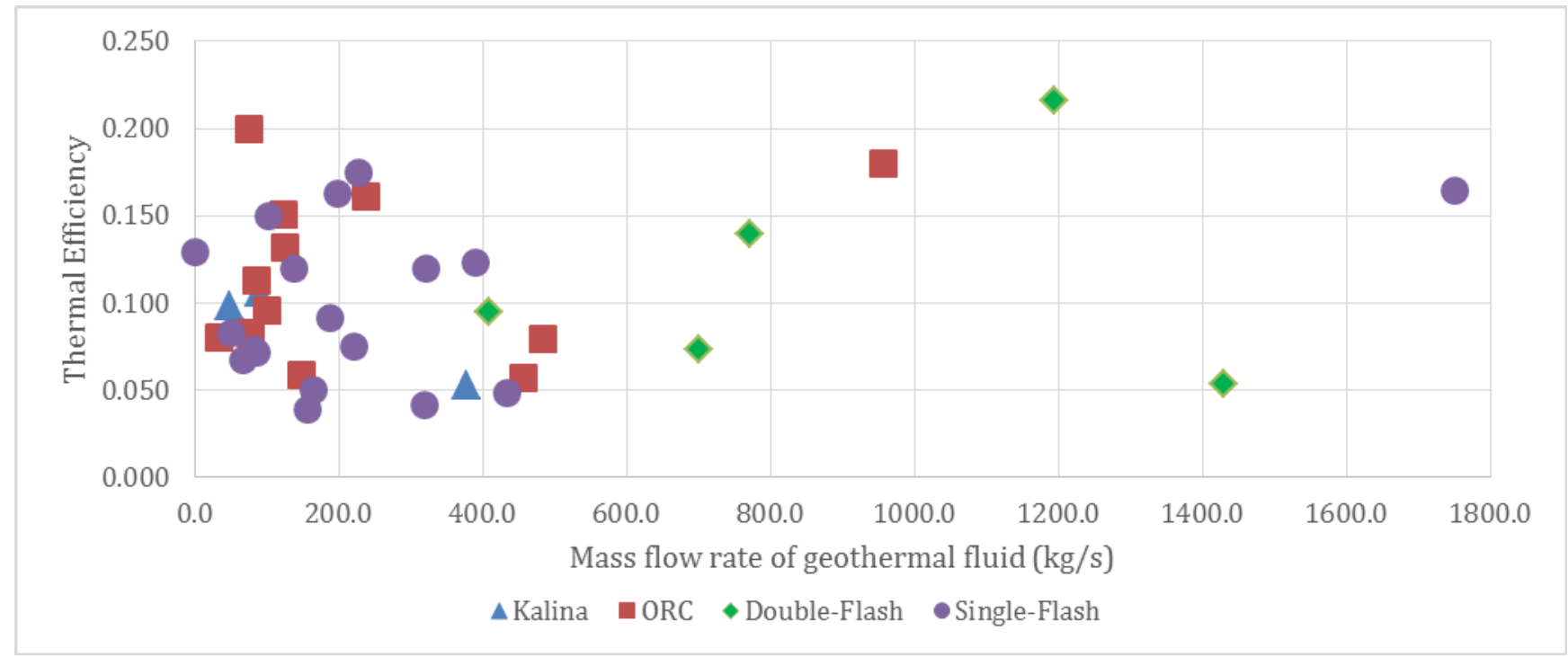

Figure 9. Thermal efficiency variation with mass flow rate.

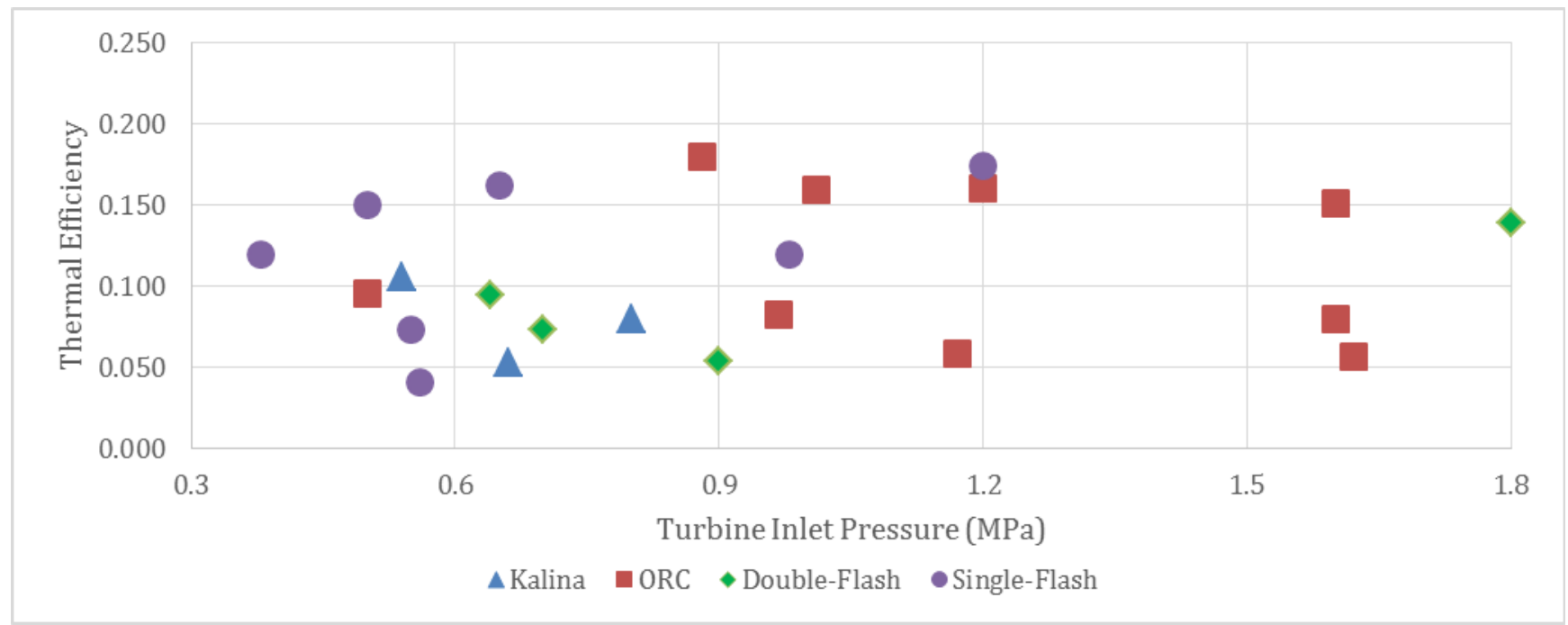

Figure 10. Thermal efficiency variation with turbine inlet pressure. 


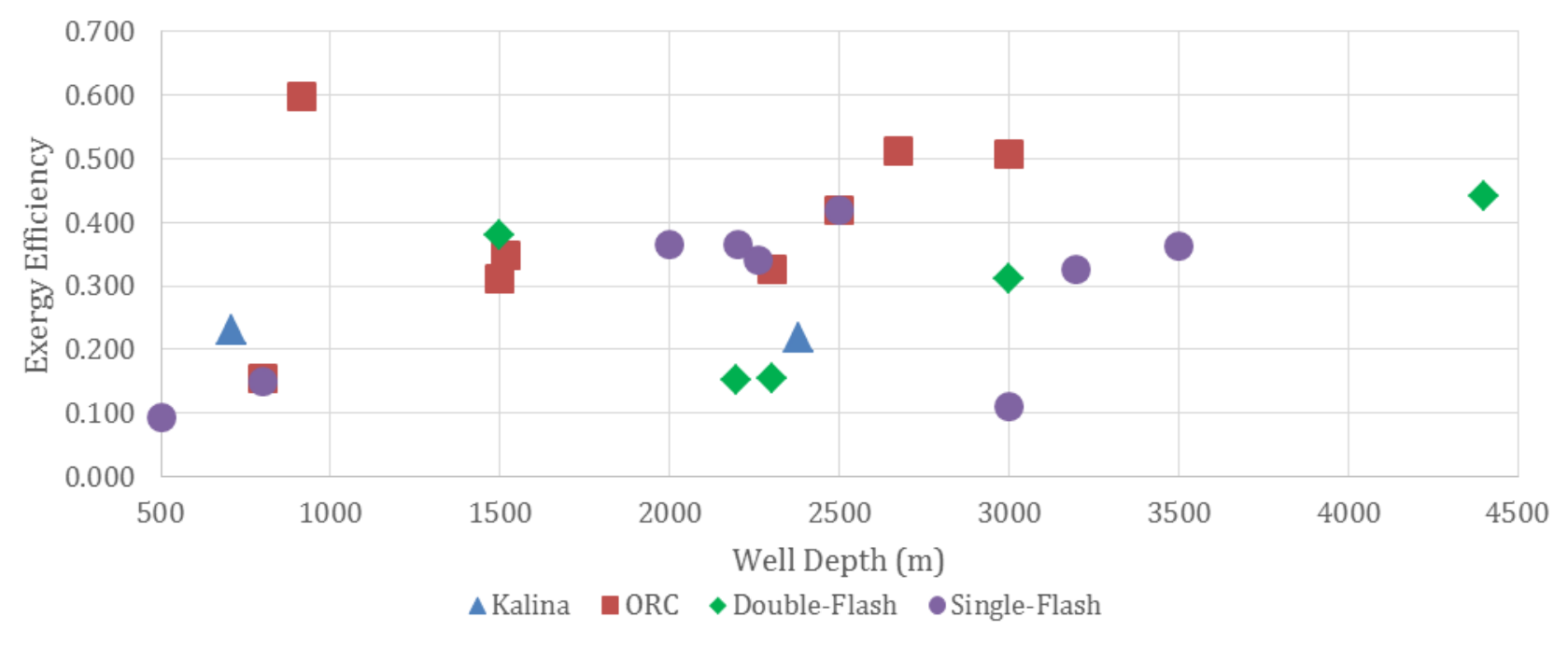

Figure 11. Exergy efficiency variation with maximum well depth.

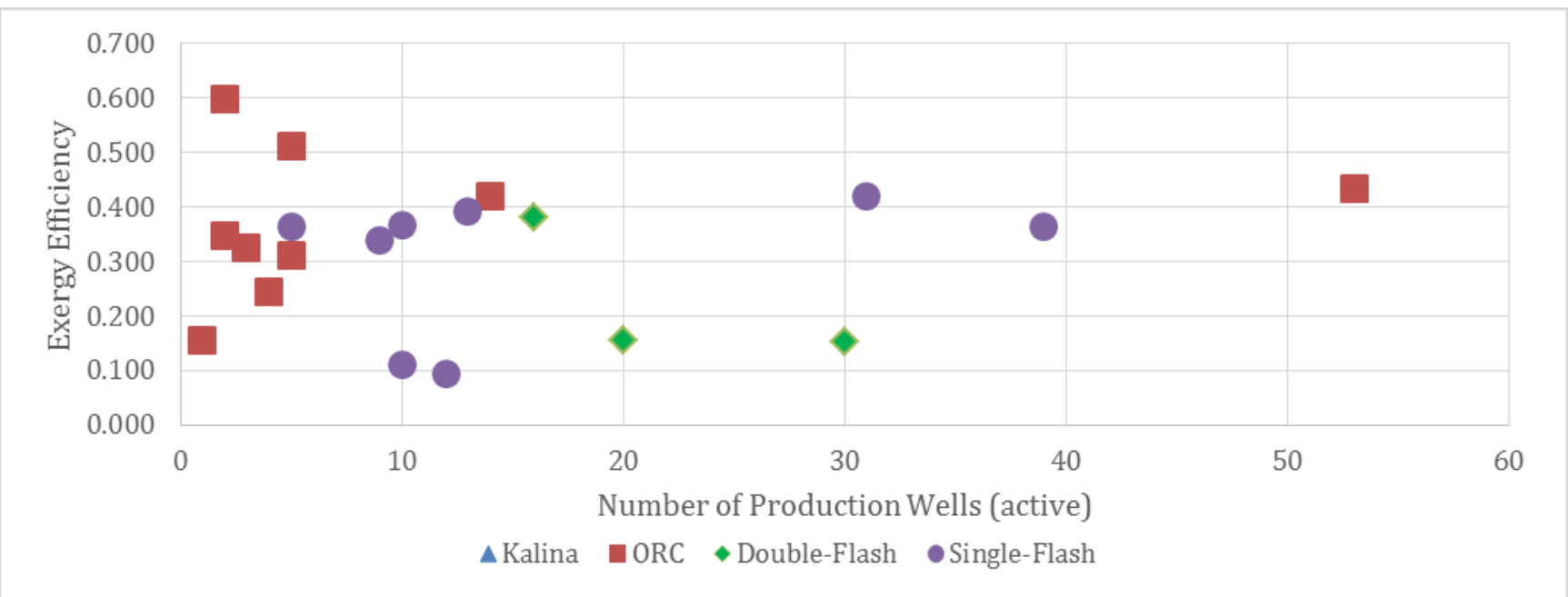

Figure 12. Exergy efficiency variation with number of active production wells.

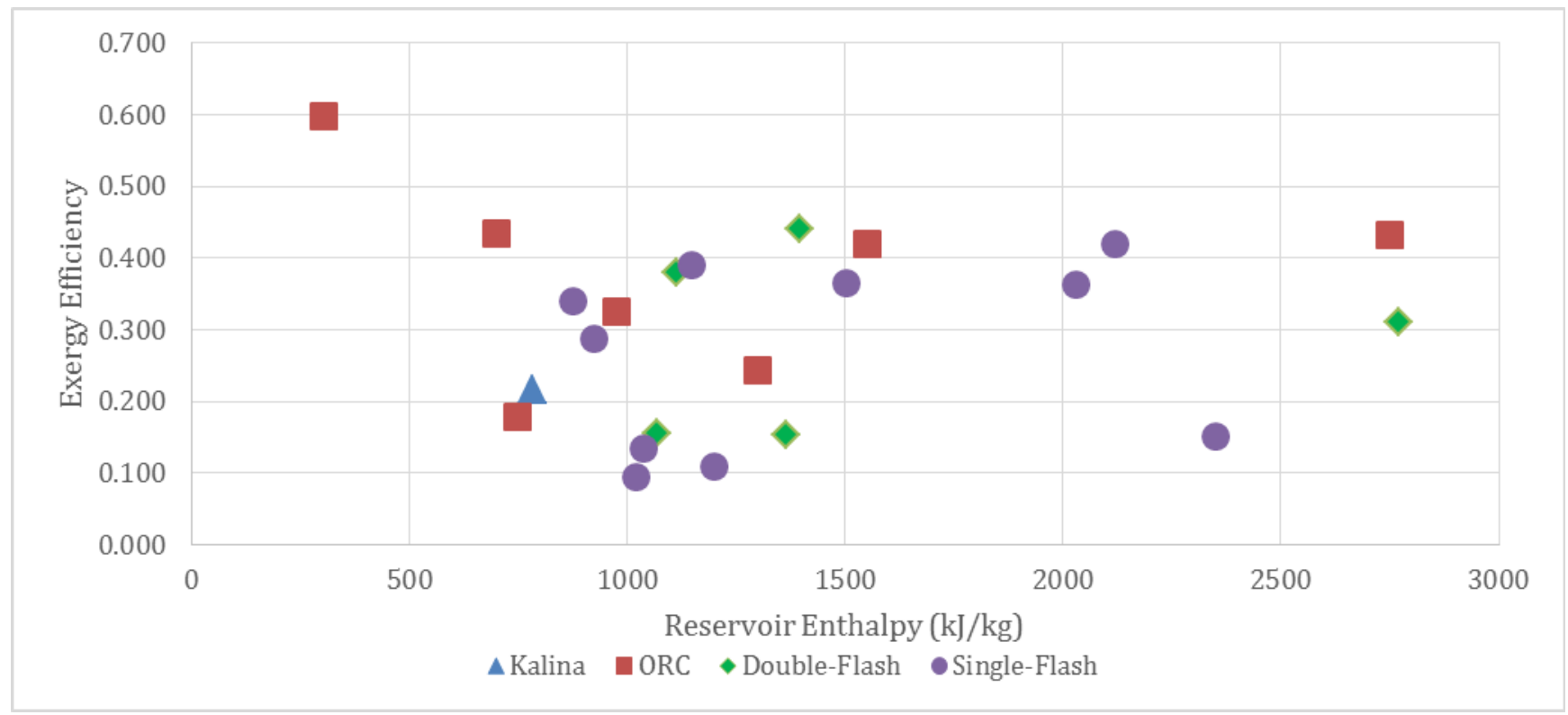

Figure 13. Exergy efficiency variation with reservoir enthalpy. 


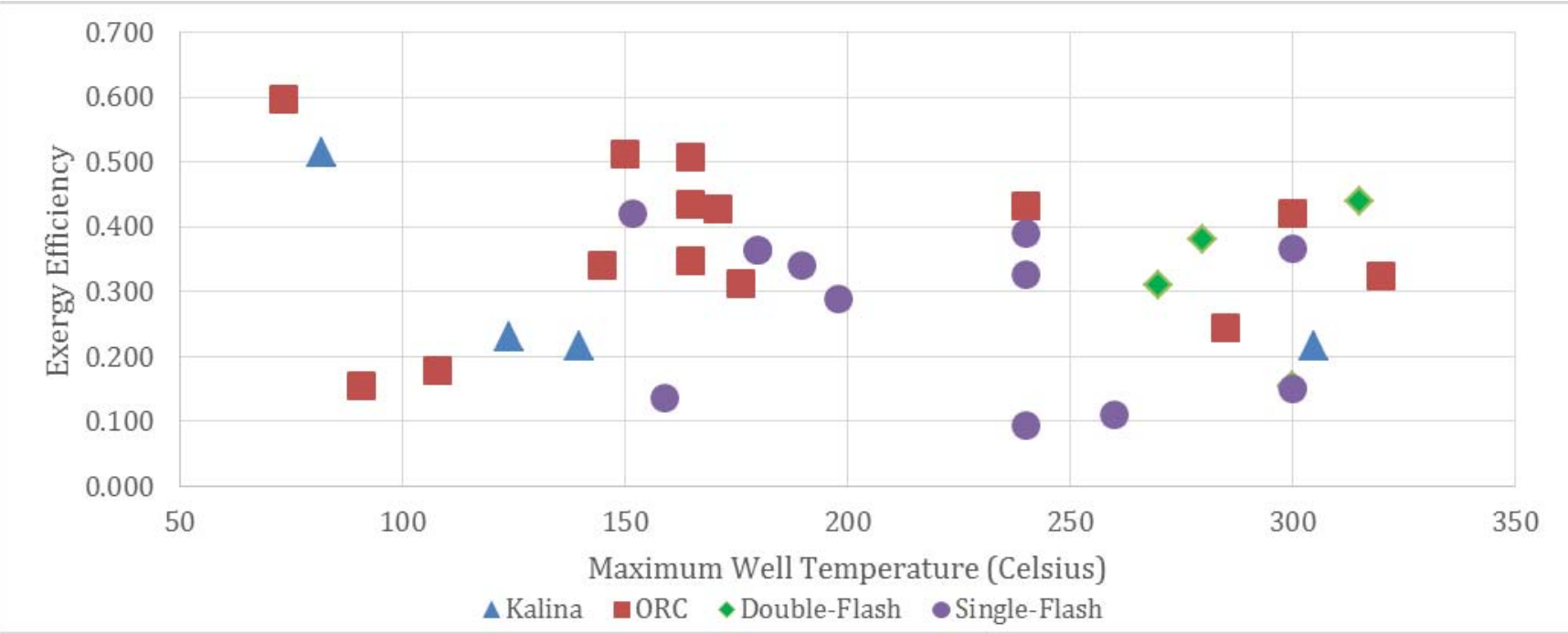

Figure 14. Exergy efficiency variation with maximum well temperature.

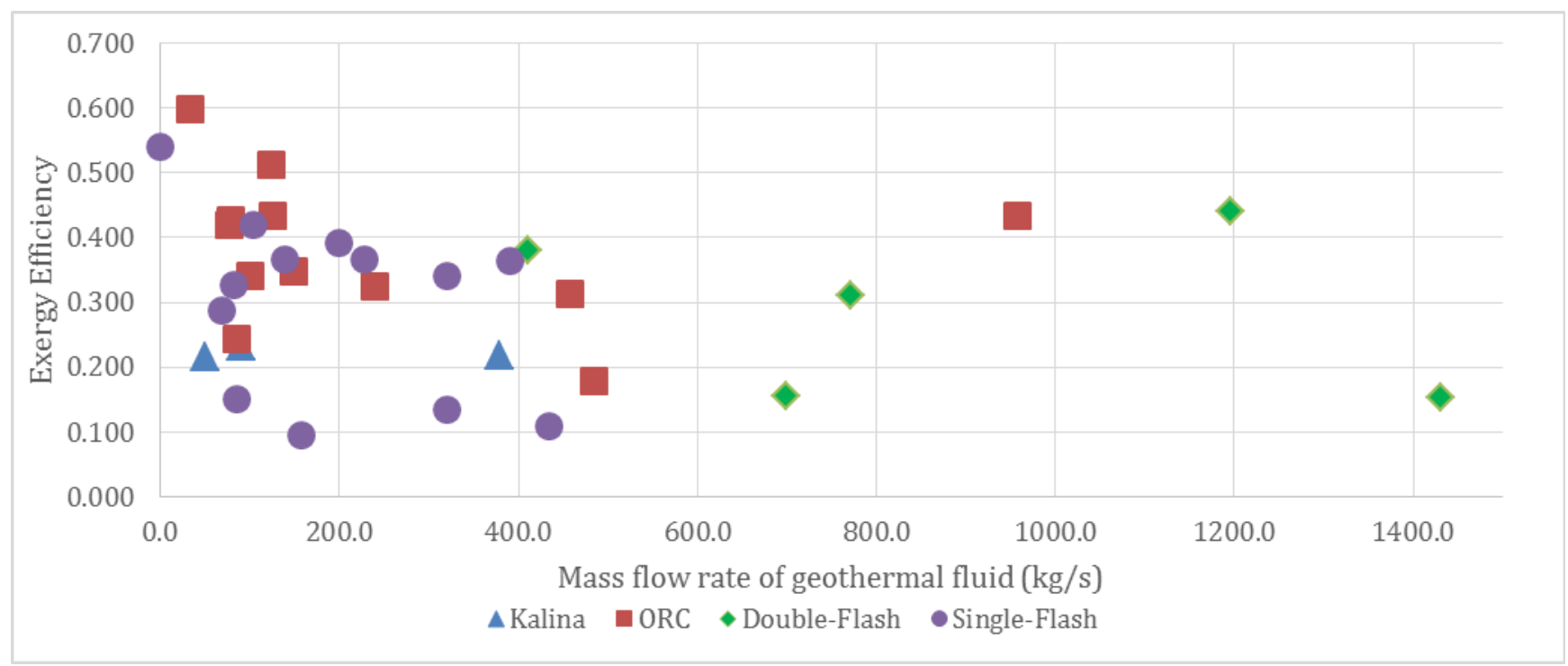

Figure 15. Exergy efficiency variation with mass flow rate.

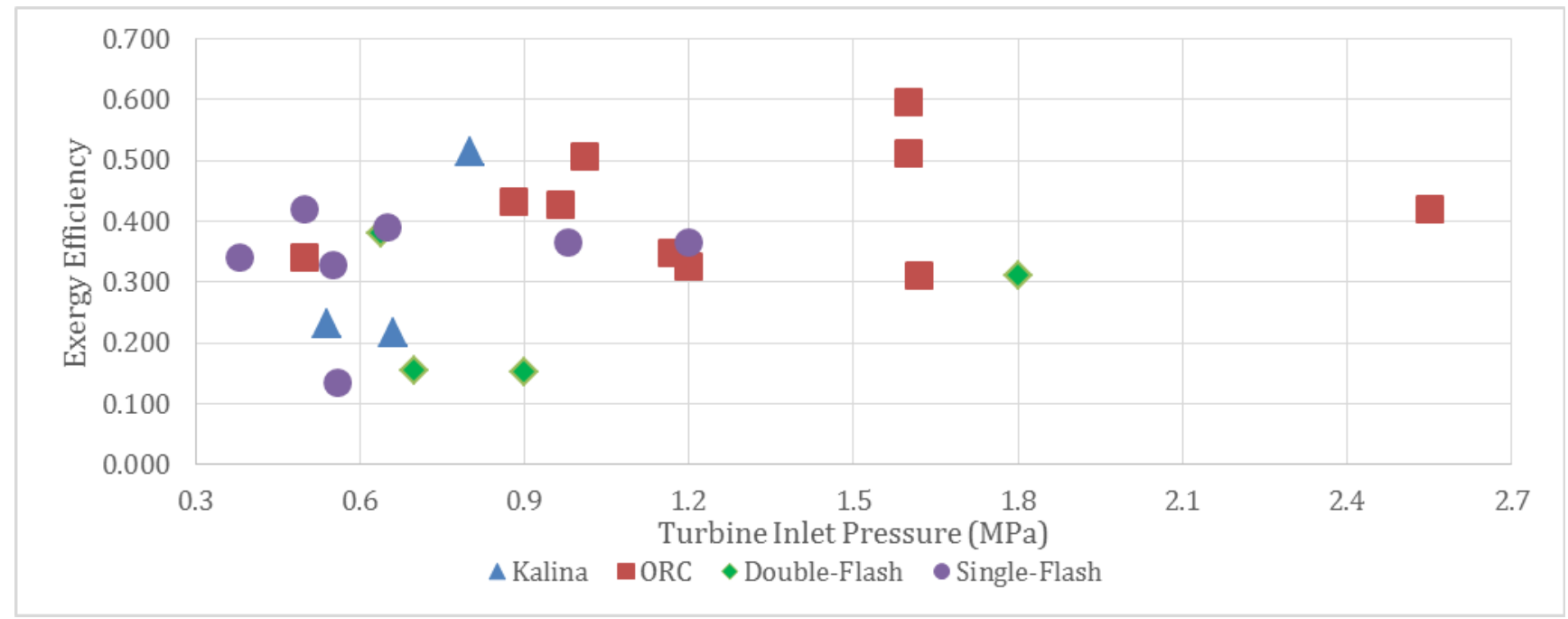

Figure 16. Exergy efficiency variation with turbine inlet pressure.

As it can be observed from the above graphs, there is no direct correlation between many of the parameters investigated in conjunction with the thermal and exergy efficiency. There are no clear 


\section{PAM Review 2016}

trends between thermal efficiency and number of production wells or mass flow rate that can be inferred from the results of this investigation. The same is true for exergy efficiency and these two variables. One possible reason for this is that total mass flow rate does not necessarily correlate with the number of wells, as can be inferred from figure 17. Furthermore, total mass flow rate is not a good indicator of plant performance because it fluctuates significantly depending on the time of the year, as well as changes in the reservoir itself and the conditions of the piping used within the plant. It would normally be expected that the mass flow rate increases with the number of wells as this usually allows for a larger volume of fluid to be transported in the same amount of time, but three key factors that were not taken into account in this study are: geothermal fluid density, pipe diameter and pipe friction. Also, wells used in the same geothermal plant often vary in depth, size and geological conditions, which makes the flow rates even less predictable. A similar lack of correlation was observed for exergy efficiency in figures 12 and 15.

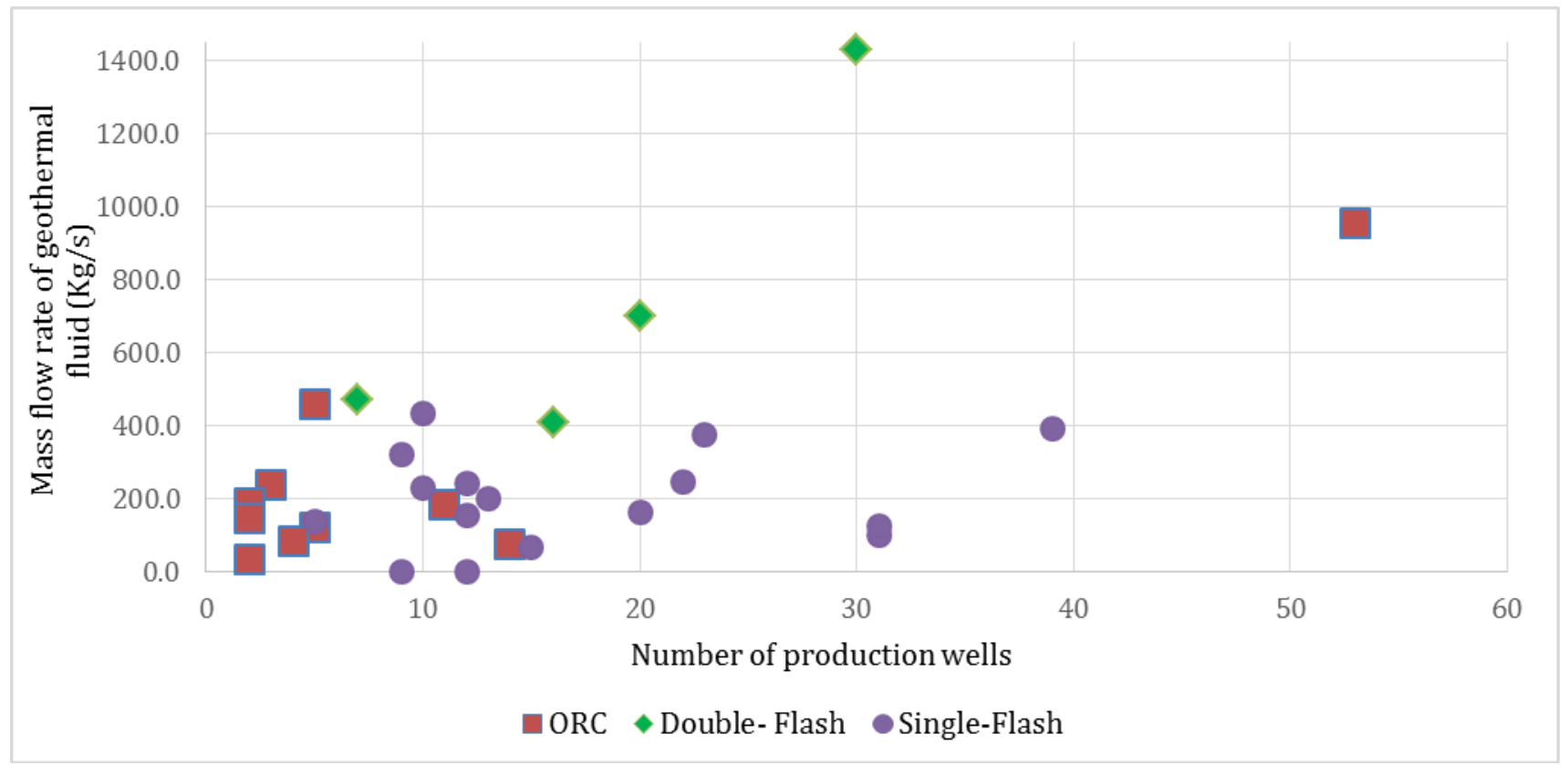

Figure 17. Mass flow rate variation with number of production wells.

A few trends were noticed, however. The variation of thermal efficiency with well depth shows a steady increase in efficiency with increasing depth for both double-flash and ORC cycle power plants. For single-flash, there is little variation but the data suggests that there is a small increase in thermal efficiency with well depth, as shown in figure 5. Since there were very few Kalina power plants included in this study (partly due to the fact that not many active geothermal plants implement the Kalina cycle at present), the data within this area is currently insufficient to draw any valid conclusions from the scatter plots, so for the rest of the analysis it was disregarded altogether. The same trends were observed for the variation of exergy efficiency with well depth.

Figures 7 and 8 show that there is a steady increase in the thermal efficiency of ORC power plants with reservoir enthalpy and maximum well temperature. The other cycles do not suggest any correlation between the variables. The exergy efficiency variation with respect to these two parameters is even less suggestive of any trends, as can be observed from figures 13 and 14. Other parameters such as turbine inlet pressure provided no valid conclusive data. 
It is evident that of the 61 geothermal power plants the group of able research there is not enough data for performing an analysis at this scale. At least twice as many should be used in future studies in order to guarantee more useful observations and correlation among the data. In light of these results, it is not possible to make any concrete recommendations for the design or construction of a geothermal power plant in the Perth Basin, Western Australia.

\section{Conclusions}

The study hereby presented investigated the thermal and exergy efficiency of 61 geothermal power plants from around the world with respect to parameters such as well depth, reservoir enthalpy, well temperature, number of wells, turbine inlet pressure and mass flow rate. From the research performed, no useful trends could be found for most of the variables involved. Thermal and exergy efficiency only seem to increase with well depth, and this is only true for ORC and double-flash cycles. The results from this study suggest that well depth may be a good indicator of efficiency in ORC and double-flash geothermal power plants, but the same cannot be said for single-flash and Kalina.

There are several reasons why the analysis may have failed to encounter more data correlation between the variables investigated. Firstly, a lot of data points were missing in all the variables (e.g. mass flow rate, well temperature). Some of this information was simply unavailable for some of the power plants researched, or perhaps was never published in official journals or conference papers. This had a huge impact in the results as some of this missing data was necessary for calculating theoretical values for thermal and exergy efficiencies (as can be seen in Appendix A). As a result, less than 50 of the 61 geothermal power plants had a relatively complete set of data for the parameters we had set to research into. Another possible reason for not encountering enough trends is the fact that there are a lot more variables that affect the performance of the plant for each of the variables investigated. For instance, fluid density, pipe diameter and pipe friction (or roughness) all play a key role in determining the maximum mass flow rate that is attainable in a particular system, irrespective of the thermodynamic cycle being used. And finally, all the power plants investigated had completely different sizes and relatively different operating conditions due to geographical locations; and this may have had an impact on the results as well.

In conclusion it can be said that the parameters studied in this paper do not have a direct impact on the efficiency of geothermal power plants. There are many more variables that must be taken into account, and quantifying the overall performance of a geothermal power plant is a very difficult task as sometimes there may be more than 20 steps involved, and in each there may be significantly different processes happening. This suggests that overall power plant performance is not additive, and that individual processes must be studied for a much more accurate analysis.

From taking into account the data presented in this report into the various parameters that would affect a geothermal plant, we as of yet cannot establish the most viable option for a geothermal plant to be implemented in the Perth Basin. Until a larger association of plants have published results for the various designs currently being implemented; the design of new geothermal plants will still require a lot of experimentation on the specific geothermal regions. 


\section{PAM Review 2016}

\section{Acknowledgments}

The authors would like to acknowledge the support and guidance of Jurgen Schulte from the University of Technology, Sydney, Australia; and for assisting in the review of this paper. Along with the Energy Science and technology class for their contribution through individual peer reviews.

\section{References and Notes}

1. Lemons, D.S., 2009. Mere thermodynamics. JHU Press.

2. DiPippo, R., 2012. Geothermal power plants: principles, applications, case studies and environmental impact. Butterworth-Heinemann. doi: http://dx.doi.org/10.1016/b978-0-08-087872$\underline{0.00708-3}$

3. Cao, L., Wang, J., Zhao, P. and Dai, Y., 2016. Thermodynamic comparison among double-flash flash-Kalina and flash-ORC geothermal power plants.International Journal of Thermodynamics, 19(1), pp.53-60. doi: http://dx.doi.org/10.5541/ijot.5000156088

4. Victor, R.A., Kim, J.K. and Smith, R., 2013. Composition optimisation of working fluids for organic Rankine cycles and Kalina cycles. Energy, 55, pp.114-126. doi: http://dx.doi.org/10.1016/j.energy.2013.03.069

5. Proctor, M.J., Yu, W., Kirkpatrick, R.D. and Young, B.R., 2016. Dynamic modelling and validation of a commercial scale geothermal organic Rankine cycle power plant. Geothermics, 61, pp.63-74. doi: http://dx.doi.org/10.1016/j.geothermics.2016.01.007

6. Doroodchi, E. \& Moghtaderi, B., 2009. State of the art in power cycles for geothermal applications and bottoming cycles, Callaghan: The University of Newcastle Australia.

7. Sheldon, H.A., Florio, B., Trefry, M.G., Reid, L.B., Ricard, L.P. and Ghori, K.A.R., 2012. The potential for convection and implications for geothermal energy in the Perth Basin, Western Australia. Hydrogeology Journal, 20(7), pp.1251-1268. doi: http://dx.doi.org/10.1007/s10040-012$\underline{0886-7}$

8. Pujol, M., Ricard, L.P. and Bolton, G., 2015. 20 years of exploitation of the Yarragadee aquifer in the Perth Basin of Western Australia for direct-use of geothermal heat. Geothermics, 57, pp.39-55. doi: http://dx.doi.org/10.1016/j.geothermics.2015.05.004

9. Coskun, A., Bolatturk, A. and Kanoglu, M., 2016. Thermodynamic analysis and optimization of various power cycles for a geothermal resource. Energy Sources, Part A: Recovery, Utilization, and Environmental Effects, 38(6), pp.850-856. doi: http://dx.doi.org/10.1080/15567036.2013.805285

10. Luo, C., Huang, L., Gong, Y. and Ma, W., 2012. Thermodynamic comparison of different types of geothermal power plant systems and case studies in China. Renewable energy, 48, pp.155-160. doi: http://dx.doi.org/10.1016/j.renene.2012.04.037

11. Rodríguez, C.E.C., Palacio, J.C.E., Venturini, O.J., Lora, E.E.S., Cobas, V.M., dos Santos, D.M., Dotto, F.R.L. and Gialluca, V., 2013. Exergetic and economic comparison of ORC and Kalina cycle for low temperature enhanced geothermal system in Brazil. Applied Thermal Engineering,52(1), pp.109-119. doi: http://dx.doi.org/10.1016/j.applthermaleng.2012.11.012

12. Hettiarachchi, H.M., Golubovic, M., Worek, W.M. and Ikegami, Y., 2007. Optimum design criteria for an organic Rankine cycle using low-temperature geothermal heat sources. Energy, 32(9), pp.1698-1706. doi: http://dx.doi.org/10.1016/j.energy.2007.01.005 
13. Zhang, X. \& He, M., 2012. A review of research on the Kalina cycle. A review of research on the Kalina cycle, 16(7), p. 5309-5318.

14. Modi, A. \& Haglind, F., 2015. Thermodynamic optimisation and analysis of four Kalina cycle layouts for high temperature applications. Applied Thermal Engineering, 76(5), p. 196-205. doi: http://dx.doi.org/10.1016/j.applthermaleng.2014.11.047

15. Lund, J. W., 2010. Direct Utilization of Geothermal Energy. Energies, 3(8), pp. 1443-1471. doi: http://dx.doi.org/10.3390/en3081443

16. Lazard, 2014. Lazard's levelized cost of energy analysis - Version 8.0. Available at: https://www.lazard.com/media/1777/levelized_cost_of_energy___version_80.pdf, accessed on May 1, 2016.

17. Mims, C., 2009. Can Geothermal Power Compete with Coal on Price?. Scientific American.

18. Li, K., 2013. International Geothermal Association. Available at: http://www.geothermalenergy.org/pdf/IGAstandard/SGW/2013/Li.pdf, accessed May 1, 2016.

19. Current List of Geothermal Power Plants, available at: http://globalenergyobservatory .org/list.php? $\mathrm{db}=$ PowerPlants\&type=Geothermal, accessed May $8^{\text {th }}, 2016$.

20. New Zealand Geothermal available at: http://www.nzgeothermal.org.nz/nz geo fields.html, accessed May $8^{\text {th }}, 2016$.

21. Bertani, R., 2005. World geothermal power generation in the period 20012005. Geothermics, 34(6), pp.651-690. doi: http://dx.doi.org/10.1016/j.geothermics.2005.09.005

22. Bertani, R., 2012. Geothermal power generation in the world 2005-2010 update report. Geothermics, 41, pp.1-29. doi: http://dx.doi.org/10.1016/i.geothermics.2011.10.001

23. Carey, B., Dunstall, M., McClintock, S., White, B., Bignall, G., Luketina, K., Robson, B., Zarrouk, S. and Seward, A., 2015. 2015 New Zealand country update. In Proceeding, World Geothermal Congress (p. 16).

24. Prevost, J.K.J., 2004. The geothermal energy industry of El Salvador. Term Paper-ESD. 166J Sustainable Energy, Spring.

25. Quijano, J., 2000, May. Exergy analysis for the Ahuachapan and Berlin geothermal fields, El Salvador. In Proceedings world geothermal congress(pp. 861-865).

26. Asturias, F., 2008, August. Geothermal resources and development in Guatemala. In 30th Anniversary Workshop of the United Nations University Geothermal Training Programme (pp. 26-27). 27. Austria Jr, J.J.C., 2008. Production capacity assessment of the Bacon-Manito geothermal reservoir, Philippines. United Nations University, Geothermal Training Programme.

28. Pambudi, N.A., Itoi, R., Jalilinasrabady, S. and Jaelani, K., 2014. Exergy analysis and optimization of Dieng single-flash geothermal power plant.Energy Conversion and Management, 78, pp.405-411. doi: http://dx.doi.org/10.1016/j.enconman.2013.10.073

29. Yildirim, D. and Ozgener, L., 2012. Thermodynamics and exergoeconomic analysis of geothermal power plants. Renewable and Sustainable Energy Reviews, 16(8), pp.6438-6454. doi: http://dx.doi.org/10.1016/j.rser.2012.07.024

30. Ganjehsarabi, H., Gungor, A. and Dincer, I., 2012. Exergetic performance analysis of Dora II geothermal power plant in Turkey. Energy, 46(1), pp.101-108. doi: http://dx.doi.org/10.1016/j.energy.2012.02.039

31. Zarrouk, S.J. and Moon, H., 2014. Efficiency of geothermal power plants: A worldwide review. Geothermics, 51, pp.142-153. doi: http://dx.doi.org/10.1016/j.geothermics.2013.11.001 


\section{PAM Review 2016}

32. Thain, I.A. and Carey, B., 2009. Fifty years of geothermal power generation at Wairakei. Geothermics, 38(1), pp.48-63. doi: http://dx.doi.org/10.1016/j.geothermics.2008.12.004 33. Miranda-Herrera, C. A. 2015. Geothermal and Solar Energy in Cerro Prieto. In Proceedings World Geothermal Congress 2015.

34. Björnsson, S., 2006. Geothermal development and research in Iceland. Orkustofnun.

Kawazoe, S. and Combs, J., 2004. Geothermal Japan. Geothermal Resources Council Bulletin, 33(2), pp.58-62.

35. Razzano, F. and Cei, M., 2015. Geothermal Power Generation in Italy 2010-2014 Update Report. In Proceedings World Geothermal Congress 2015 (pp. 19-24).

36. Flores-Armenta, M. and Gutiérrez-Negrín, L.C., 2011. Geothermal activity and development in Mexico. Short Course on Geothermal Drilling, Resource Development and Power Plants, UNU-GTP and LaGeo, Santa Tecla, El Salvador.

37. Sifford, A. and Bloomquist, R.G., 2000. Geothermal Electric Power Production in the United States: A Survey Update for 1995-1999.TRANSACTIONS-GEOTHERMAL RESOURCES COUNCIL, pp.389-396.

38. Domanski, I., Cappadona, M., Fuller, O. and Krix, Z., 2015. Geothermal Power: Factors affecting the performance of Binary Plants. PAM Review: Energy Science \& Technology, 2, pp.32-49. doi: http://dx.doi.org/10.5130/pamr.v2i0.1394

39. Yahara, T. and Tokita, H., 2010. Sustainability of the Hatchobaru geothermal field, Japan. Geothermics, 39(4), pp.382-390. doi: http://dx.doi.org/10.1016/j.geothermics.2010.09.001

40. Sigfusson, B., Gunnarsson, I. and Energy, R., 2011. Scaling prevention experiments in the hellisheiði power plant, Iceland. In Proceedings, thirty-sixth workshop on geothermal reservoir engineering, Stanford University, Stanford, California, SGP-TR-191.

41. Simiyu, S.M., 2010, April. Status of geothermal exploration in Kenya and future plans for its development. In Proceedings world geothermal congress.

42. Nielsen, G., Maack, R., Gudmundsson, A. and Gunnarsson, G.I., 2000. Completion of Krafla geothermal power plant. In Proc. World Geothermal Congress.

43. Emoricha, E.B., Omagbon, J.B. and Malate, R.C.M., 2010. Three dimensional numerical modelling of Mindanao geothermal production field, Philippines. In Proceedings of the 35th workshop on geothermal reservoir engineering, Stanford, California (USA).

44. Moya, P. and DiPippo, R., 2007. Unit 5 bottoming binary plant at Miravalles geothermal field, Costa Rica: Planning, design, performance and impact.Geothermics, 36(1), pp.63-96. doi: http://dx.doi.org/10.1016/j.geothermics.2006.10.003

45. Porras, E.A. and Bjornsson, G., 2010. The Momotombo reservoir performance upon 27 years of exploitation. In Proceedings world geothermal congress, Bali, Indonesia.

46. Hanano, M., Kajiwara, T., Hishi, Y., Arai, F., Asanuma, M., Sato, K. and Takanohashi, M., 2005, April. Overview of production at the Mori geothermal field, Japan. In Proceedings world geothermal congress (pp. 24-29).

47. Ballzus, C., Frimannson, H., Gunnarsson, G.I. and Hrolfsson, I., 2000. The geothermal power plant at Nesjavellir, Iceland. In Proc. World Geothermal Congress.

48. Legmann, H. 2015. The 100-MW Ngatamariki Geothermal Power Station: A purpose-built plant for high temperature, high enthalpy resource. In Proc. World Geothermal Congress. 
49. Butler, S.J., Sanyal, S.K., Klein, C.W., Iwata, S. and Itoh, M., 2005, April. Numerical simulation and performance evaluation of the Uenotai geothermal field, Akita Prefecture, Japan. In Proceedings, World Geothermal Congress Antalya, Turkey (pp. 24-29).

50. Itoi, R., Kumamoto, Y., Tanaka, T. and Takayama, J., 2010. History matching simulation of the Ogiri geothermal field, Japan. In Proceedings world geothermal congress, Bali, Indonesia.

51. Kwambai, C.B., 2005. Energy analysis of Olkaria I power plant, Kenya. United Nations University.

Mwangi, M., 2005, April. Country update report for Kenya 2000-2005. In Proceedings (pp. 24-29).

52. Moya, P. and DiPippo, R., 2012. Las Pailas 35 MW (net) binary power plant, Rincón de la Vieja, Guanacaste, Costa Rica. GRC Transactions, 36, pp.1155-1164.

53. Mazurek, R., 2011. Modeling and thermoeconomic analysis of the municipal CHP station (PEC) in Stargard Szczecinski (Doctoral dissertation, Master's thesis done at RES| The School for Renewable Energy Science in affiliation with University of Iceland \& University of Akureyri, 87pp).

54. Yamaguchi, N., 2010, April. Variety of steam turbines in svartsengi and reykjanes geothermal power plants. In Proceedings, World geothermal Congress, Bali: Indonesia (pp. 25-29).

55. Jalilinasrabady, S., Itoi, R., Gotoh, H. and Kamenosono, H., 2010. Energy and exergy analysis of Takigami geothermal power plant, Oita, Japan.Geothermal Resources Council Transactions, 34, pp.1057-1062.

56. Horie, T., Muto, T. and Gray, T., 2010, April. Technical Features of Kawerau Geothermal Power Station, New Zealand. In Proceedings of World Geothermal Congress, Bali, Indonesia.

57. Asturias, F., 2003. Reservoir assessment of Zunil I \& II geothermal fields, Guatemala.

58. DiPippo, R., 2004. Second law assessment of binary plants generating power from lowtemperature geothermal fluids. Geothermics, 33(5), pp.565-586. doi: http://dx.doi.org/10.1016/j.geothermics.2003.10.003

59. Holdmann, G. and List, K., 2007, June. The Chena Hot Springs 400kW geothermal power plant: experience gained during the first year of operation. In GRC Conference.

60. Aneke, M., Agnew, B. and Underwood, C., 2011. Performance analysis of the Chena binary geothermal power plant. Applied Thermal Engineering, 31(10), pp.1825-1832. doi: http://dx.doi.org/10.1016/j.applthermaleng.2011.02.028

61. Chena Geothermal Area, available at: http://en.openei.org/wiki/Chena_Geothermal_Area, accessed on May $9^{\text {th }}, 2016$.

62. HUANG, L., 2015. The Case Studies of Mid-low Temperature Geothermal Power Plant in China. In Proceedings World Geothermal Congress.

63. Jalilinasrabady, S., Itoi, R., Fujii, H. and Tanaka, T., 2010. Energy and exergy analysis of Sabalan geothermal power plant, IRAN. In Proceedings, World Geothermal Congress.

64. Noorollahi, Y. and Itoi, R., 2011. Production capacity estimation by reservoir numerical simulation of northwest (NW) Sabalan geothermal field, Iran.Energy, 36(7), pp.4552-4569. doi: http://dx.doi.org/10.1016/j.energy.2011.03.046

65. Moya, P. and DiPippo, R., 2010, April. Miravalles unit 3 single-flash plant, Guanacaste, Costa Rica: technical and environmental performance assessment. In Proceedings of World Geothermal Congress, Bali, Indonesia.

66. Puente, H.G. and Rodriguez, M.H., 2000, May. 28 years of production at Cerro Prieto geothermalfield. In Proc. World Geothemal Congress. Japan (pp. 855-859). 
67. International Geothermal Association, available at: http://www.geothermalenergy.org/publications and_services/conference_paper_database.html, accessed on May 9 ${ }^{\text {th }}, 2016$. 68. Gokcen, G., Ozturk, H.K. and Hepbasli, A., 2004. Overview of Kizildere geothermal power plant in Turkey. Energy conversion and management, 45 (1), pp.83-98. doi: http://dx.doi.org/10.1016/S0196-8904(03)00129-8 
Appendix A - Tabulated data from geothermal power plants
Legend: GPP - Geothermal Power Plant
DF - Double-Flash
$\mathrm{P}$ - Pentane organic fluid
BK - Binary Kalina
$\mathrm{SF}$ - Single-Flash
N-P - N-Pentane organic fluid
ORC - Binary Organic Rankine Cycle
AW - Ammonia-Water mixture
IP - Isopentane organic fluid

* Refers to those plants for which thermal efficiency and exergy efficiency needed to be calculated using equations 1 and 2 as this information was not available elsewhere.

\begin{tabular}{|c|c|c|c|c|c|c|c|c|c|c|c|c|}
\hline Plant name & Type & $\begin{array}{l}\text { Capacity } \\
\text { (MWe) }\end{array}$ & $\begin{array}{l}\text { Max. } \\
\text { Depth (m) }\end{array}$ & $\begin{array}{l}\text { No. Production } \\
\text { wells }\end{array}$ & $\begin{array}{l}\text { Reservoir } \\
\text { Enthalpy (kJ/kg) }\end{array}$ & $\begin{array}{l}\text { Max. temp } \\
\text { (Celsius) }\end{array}$ & $\begin{array}{l}\text { Mass flow rate } \\
(\mathrm{kg} / \mathrm{s})\end{array}$ & $\begin{array}{l}\text { Turbine Inlet } \\
\text { Pressure (MPa) }\end{array}$ & $\begin{array}{l}\text { Binary } \\
\text { fluid }\end{array}$ & $\begin{array}{l}\text { Thermal } \\
\text { Efficiency }\end{array}$ & $\begin{array}{l}\text { Exergy } \\
\text { Efficiency }\end{array}$ & References \\
\hline $\begin{array}{l}\text { Berlin GPP El } \\
\text { Salvador }\end{array}$ & BK & & 2380 & & 785 & 305 & 378.0 & 0.66 & AW & 0.053 & 0.217 & [25] \\
\hline $\begin{array}{l}\text { Zunil GPP } \\
\text { Guatemala }\end{array}$ & BK & & 2370 & & & 300 & 0.0 & & AW & & & [57] \\
\hline $\begin{array}{l}\text { Husavik GPP } \\
\text { Iceland }\end{array}$ & BK & & 710 & & & 124 & 90.0 & 0.54 & AW & 0.106 & 0.231 & {$[19,22]$} \\
\hline $\begin{array}{l}\text { Nigorikawa GPP } \\
\text { Japan }\end{array}$ & BK & & & & & 140 & 49.9 & & AW & 0.098 & 0.216 & {$[19,22]$} \\
\hline $\begin{array}{l}\text { Sanshui GPP } \\
\text { China* }\end{array}$ & BK & & & & & 82 & & 0.8 & AW & 0.080 & 0.515 & {$[19,22]$} \\
\hline $\begin{array}{l}\text { Unterhaching } \\
\text { Germany }\end{array}$ & BK & & 3500 & & & 120 & 150.0 & 2 & AW & & & {$[19,22]$} \\
\hline $\begin{array}{l}\text { Miravalles V GPP } \\
\text { Costa Rica* }\end{array}$ & ORC & 15.45 & 3000 & & & 165 & & 1.01 & $\mathrm{P}$ & 0.160 & 0.507 & [44] \\
\hline $\begin{array}{l}\text { Pailas GPP Costa } \\
\text { Rica }\end{array}$ & ORC & 36 & 2673 & 5 & & 150.1 & 123.5 & 1.6 & $\mathrm{~N}-\mathrm{P}$ & 0.151 & 0.512 & [52] \\
\hline $\begin{array}{l}\text { Amatitlan GPP } \\
\text { Guatemala* }\end{array}$ & ORC & 25.2 & & 4 & 1300 & 285 & 85.7 & & $P$ & 0.113 & 0.244 & {$[21,22]$} \\
\hline $\begin{array}{l}\text { Ngawha GPP New } \\
\text { Zealand* }\end{array}$ & ORC & 75 & 2300 & 3 & 975 & 320 & 239.4 & 1.2 & $P$ & 0.161 & 0.325 & {$[20,22]$} \\
\hline $\begin{array}{l}\text { Wairakei GPP New } \\
\text { Zealand }\end{array}$ & ORC & 171 & & 53 & 2750 & 240 & 957.6 & 0.88 & IP & 0.180 & 0.433 & [32] \\
\hline $\begin{array}{l}\text { Te Huka GPP New } \\
\text { Zealand }\end{array}$ & ORC & 23 & & 2 & & & 189.0 & 0.9 & $N-P$ & & & {$[20,22]$} \\
\hline $\begin{array}{l}\text { Ngatamariki GPP } \\
\text { New Zealand }\end{array}$ & ORC & 100 & 3373 & 3 & & 290 & & 1.22 & $P$ & & & [48] \\
\hline $\begin{array}{l}\text { Mokai GPP New } \\
\text { Zealand }\end{array}$ & ORC & 110 & & 11 & & 326 & 184.0 & 1.8 & $\mathrm{~N}-\mathrm{P}$ & & & [20] \\
\hline $\begin{array}{l}\text { Rotokawa GPP } \\
\text { New Zealand* }\end{array}$ & ORC & 34 & 2500 & 14 & 1550 & 300 & 76.4 & 2.55 & $\mathrm{P}$ & 0.200 & 0.420 & {$[20,21]$} \\
\hline $\begin{array}{l}\text { Chena Hot Springs } \\
\text { GPP USA* }\end{array}$ & ORC & 0.21 & 915 & 2 & 306 & 73.3 & 33.4 & 1.6 & R-134a & 0.080 & 0.597 & {$[59,60,61]$} \\
\hline
\end{tabular}


PAM Review 2016

\begin{tabular}{|c|c|c|c|c|c|c|c|c|c|c|c|c|}
\hline $\begin{array}{l}\text { Brady Hot Springs } \\
\text { GPP USA }\end{array}$ & ORC & 4.33 & & & 750 & 108 & 484.1 & & $\mathrm{~N}-\mathrm{P}$ & 0.080 & 0.179 & [22] \\
\hline Heber GPP USA & ORC & 6.87 & & & 702 & 165 & 126.0 & & $\mathrm{~N}-\mathrm{P}$ & 0.132 & 0.434 & {$[19,22]$} \\
\hline Dora 1 GPP Turkey & ORC & 7.3 & 1517 & 2 & & 165 & 148.4 & 1.17 & $\mathrm{~N}-\mathrm{P}$ & 0.059 & 0.347 & {$[22]$} \\
\hline Dora 2 GPPTurkey & ORC & 9.8 & 1500 & 5 & & 176 & 457.9 & 1.62 & $\mathrm{~N}-\mathrm{P}$ & 0.057 & 0.312 & [30] \\
\hline Tuzla GPP Turkey & ORC & 7.5 & & & & 171 & 77.9 & 0.967 & IP & 0.083 & 0.427 & [22] \\
\hline $\begin{array}{l}\text { Bereket GPP } \\
\text { Turkey* }\end{array}$ & ORC & 6.35 & & & & 145 & 100.8 & 0.5 & $\mathrm{~N}-\mathrm{P}$ & 0.096 & 0.340 & [22] \\
\hline $\begin{array}{l}\text { Fengshun GPP } \\
\text { China* }\end{array}$ & ORC & 0.3 & 800 & 1 & & 91 & & & $\mathrm{~N}-\mathrm{P}$ & 0.027 & 0.155 & [62] \\
\hline $\begin{array}{l}\text { Ahuachapan GPP El } \\
\text { Salvador }\end{array}$ & DF & 95 & 1500 & 16 & 1115 & 280 & 410.0 & 0.64 & NA & 0.095 & 0.380 & {$[22,24]$} \\
\hline $\begin{array}{l}\text { Hellisheidi GPP } \\
\text { Iceland* }\end{array}$ & $\mathrm{DF}$ & 210 & 2195 & 30 & 1365 & 300 & 1431.1 & 0.9 & NA & 0.054 & 0.153 & {$[34,40]$} \\
\hline $\begin{array}{l}\text { Larderello GPP } \\
\text { Italy* }\end{array}$ & DF & 594.5 & 3000 & 200 & 2770 & 270 & 771.1 & 1.8 & NA & 0.139 & 0.311 & [35] \\
\hline $\begin{array}{l}\text { Hatchobaru GPP } \\
\text { Japan* }\end{array}$ & DF & 110 & 2300 & 20 & 1068 & 300 & 700.0 & 0.7 & NA & 0.074 & 0.154 & [39] \\
\hline $\begin{array}{l}\text { Cerro Prieto GPP } \\
\text { Mexico* }\end{array}$ & DF & 720 & 4400 & 164 & 1396 & 315 & 1195.2 & & NA & 0.216 & 0.440 & {$[33,66]$} \\
\hline $\begin{array}{l}\text { Kawerau GPP New } \\
\text { Zealand }\end{array}$ & $\mathrm{DF}$ & 108 & 2100 & 7 & & & 472.5 & 1.2 & NA & & & [56] \\
\hline $\begin{array}{l}\text { Momotombo GPP } \\
\text { Nicaragua }\end{array}$ & $\mathrm{DF}$ & 30 & 3000 & 20 & 1250 & 240 & & & NA & & & [45] \\
\hline Mori GPP Japan* & SF & 50 & 3000 & 10 & 1199 & 260 & 434.4 & & NA & 0.048 & 0.110 & [46] \\
\hline $\begin{array}{l}\text { Matsukawa GPP } \\
\text { Japan* }\end{array}$ & SF & 23.5 & & & 2797 & & 50.7 & & NA & 0.083 & & {$[22]$} \\
\hline $\begin{array}{l}\text { Mindanao GPP } \\
\text { Philippines }\end{array}$ & SF & 106 & 2954 & 21 & 1175 & & & 1.5 & NA & & & [43] \\
\hline $\begin{array}{l}\text { Miravalles I and II } \\
\text { GPP Costa Rica }\end{array}$ & SF & 115 & 1700 & & & 255 & 35.3 & & NA & & & {$[19,22,65]$} \\
\hline $\begin{array}{l}\text { Miravalles III GPP } \\
\text { Costa Rica* }\end{array}$ & SF & 27.5 & & & 1038 & 159 & 320.6 & 0.56 & NA & 0.041 & 0.135 & {$[65]$} \\
\hline Krafla GPP Iceland & SF & 60 & 2200 & 22 & & 287 & 248.5 & 0.77 & NA & & & [42] \\
\hline $\begin{array}{l}\text { Svartsengi GPP } \\
\text { Iceland* }\end{array}$ & SF & 74.4 & & 13 & 1148 & 240 & 199.6 & 0.65 & NA & 0.162 & 0.391 & {$[54]$} \\
\hline $\begin{array}{l}\text { Reykjanes GPP } \\
\text { Iceland }\end{array}$ & SF & 150 & 2700 & 12 & & 320 & 240.9 & 1.9 & NA & & & {$[54]$} \\
\hline $\begin{array}{l}\text { Nesjavellir GPP } \\
\text { Iceland* }\end{array}$ & SF & 120 & 2200 & 10 & 1503 & 300 & 228.6 & 1.2 & NA & 0.175 & 0.366 & [47] \\
\hline Sumikawa GPP & SF & 50 & & & 1500 & & 221.3 & & NA & 0.075 & & [22] \\
\hline
\end{tabular}


PAM Review 2016

\begin{tabular}{|c|c|c|c|c|c|c|c|c|c|c|c|c|}
\hline Japan* & & & & & & & & & & & & \\
\hline $\begin{array}{l}\text { Uenotai GPP } \\
\text { Japan* }\end{array}$ & SF & 28.8 & 800 & & 2350 & 300 & 85.7 & & NA & 0.072 & 0.150 & [49] \\
\hline $\begin{array}{l}\text { Yanaizu-Nishiyama } \\
\text { GPP Japan* }\end{array}$ & SF & 65 & & & 1882 & & 189.0 & & NA & 0.091 & & {$[22]$} \\
\hline $\begin{array}{l}\text { Kakkonda GPP } \\
\text { Japan* }\end{array}$ & SF & 80 & 2500 & 29 & 992 & 360 & & & NA & & & {$[21,22]$} \\
\hline $\begin{array}{l}\text { Yamagawa GPP } \\
\text { Japan }\end{array}$ & SF & 30 & 2100 & 12 & & & 0.0 & & NA & & & {$[21,22]$} \\
\hline Onikobe GPP Japan & SF & 12.5 & 500 & 12 & 1020 & 240 & 157.5 & & NA & 0.039 & 0.094 & {$[21,22]$} \\
\hline Otake GPP Japan* & SF & 12.5 & & & & & 0.0 & & NA & 0.129 & 0.539 & {$[22]$} \\
\hline Ogiri GPP Japan & SF & 30 & 483 & 15 & & 130 & 69.3 & & NA & & & [50] \\
\hline $\begin{array}{l}\text { Takigami GPP } \\
\text { Japan }\end{array}$ & SF & 28 & & & 925 & 198 & 68.5 & & NA & 0.067 & 0.288 & [55] \\
\hline Olkaria I GPP Kenya & SF & 45 & 2500 & 31 & 2120 & 152 & 103.3 & 0.5 & NA & 0.150 & 0.420 & [51] \\
\hline $\begin{array}{l}\text { Olkaria II GPP } \\
\text { Kenya }\end{array}$ & SF & 70 & 2500 & 31 & & 160 & 127.0 & 0.5 & NA & & & [51] \\
\hline $\begin{array}{l}\text { Olkaria III GPP } \\
\text { Kenya }\end{array}$ & SF & 48 & 2750 & 9 & & & 0.0 & & NA & & & {$[51]$} \\
\hline $\begin{array}{l}\text { Los Azufres GPP } \\
\text { Mexico* }\end{array}$ & SF & 195 & 3500 & 39 & 2030 & 180 & 391.3 & & NA & 0.123 & 0.363 & {$[22,36]$} \\
\hline $\begin{array}{l}\text { Los Humeros GPP } \\
\text { Mexico* }\end{array}$ & SF & 40 & 2185 & 20 & 2413 & & 165.6 & & NA & 0.050 & & {$[22,36]$} \\
\hline $\begin{array}{l}\text { Poihipi GPP New } \\
\text { Zealand }\end{array}$ & SF & 55 & & & & 220 & 85.7 & 0.35 & NA & & & {$[19,20,23]$} \\
\hline $\begin{array}{l}\text { Ohaaki GPP New } \\
\text { Zealand }\end{array}$ & SF & 122.4 & 2500 & 23 & & 300 & 378.0 & 1 & NA & & & {$[20,23]$} \\
\hline $\begin{array}{l}\text { Tiwi GPP } \\
\text { Philippines }\end{array}$ & SF & 330 & 2784 & 48 & & & & & NA & & & [22] \\
\hline $\begin{array}{l}\text { Bacon-Manito GPP } \\
\text { Philippines }\end{array}$ & SF & 150 & 2546 & 23 & & 272 & & & NA & & & [27] \\
\hline Geysers GPP USA* & SF & 1529 & & & 2650 & & 1751.4 & & NA & 0.165 & & {$[21,22]$} \\
\hline $\begin{array}{l}\text { Dieng GPP } \\
\text { Indonesia } \\
\end{array}$ & SF & 60 & 2000 & 5 & & 180 & 138.8 & 0.98 & NA & 0.120 & 0.365 & [28] \\
\hline $\begin{array}{l}\text { Kizildere GPP } \\
\text { Turkey }\end{array}$ & SF & 20.4 & 2261 & 9 & 875 & 190 & 320.8 & 0.38 & & 0.120 & 0.340 & [68] \\
\hline Sabalan GPP Iran & SF & 36 & 3197 & & & 240 & 82.1 & 0.55 & NA & 0.073 & 0.327 & {$[63,64]$} \\
\hline $\begin{array}{l}\text { Nga Awa Purua } \\
\text { GPP New Zealand }\end{array}$ & TF & 140 & 2500 & & 1560 & 320 & & 2.42 & NA & & & {$[20,23]$} \\
\hline
\end{tabular}

